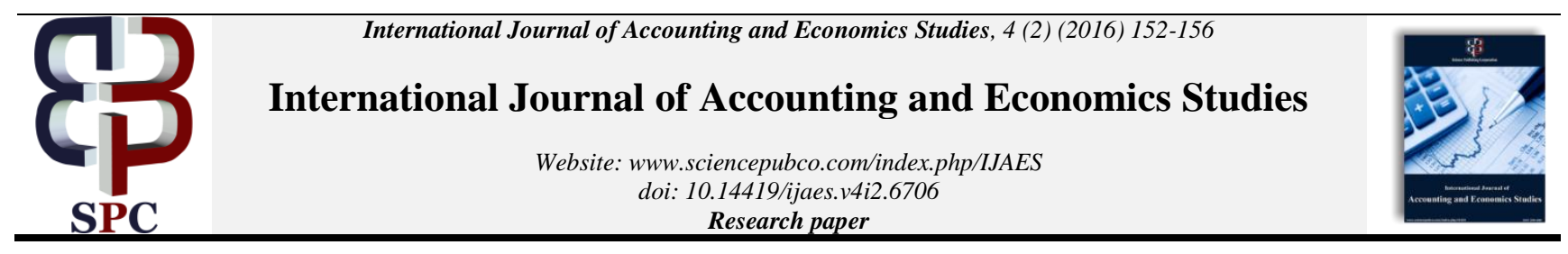

\title{
Organizational culture, law enforcement, and Indonesian tax revenue
}

\author{
Ida Farida Adi Prawira* \\ Department of Accounting, Faculty of Economic and Bussiness Education, Indonesia Education University \\ 229th Dr.Setiabudhi Street, Bandung, West Java, Indonesia 40154 \\ *Corresponding author E-mail: ida.farida@upi.edu
}

\begin{abstract}
The aim of this research is to provide empirical evidence from an examination asserting that the organizational culture influences the implementation of law enforcement and its impacts on increasing tax revenue. This study arose considering some conditions of unsatisfactory organizational culture resulting in ineffective implementation of law enforcement, and authority-misusing law enforcer. The methodology of the research is explanatory through survey approach and statistical process using SEM PLS, in order to ascertain the facts about above mentioned phenomena and acquire actual and systematic information regarding the organizational culture and the increase of tax revenue. The results of the research indicate that the increase of tax revenue was not optimum as a result of insufficient implementation of law enforcement. This condition was possibly caused by low rate of organizational culture. It is therefore concidered necessary to develop values that motivate employees to be more innovative and confident in making decision in line with prevailing regulations. DJP needs to develop prudent attitude, particularly related to employee's attention on detail. This attitude is significant to develop attentive behavior in order to gain people's trust.
\end{abstract}

Keywords: Organizational Culture; Implementation of Law Enforcement; and Increase of Tax Revenue.

\section{Introduction}

Increased tax revenue is a result of the development of climate tax that has these characteristics: 1) Taxpayers understand or attempt to understand the provisions of the tax legislation; 2) fill out a tax form correctly; 3) calculate the correct amount of tax; 4) and pay taxes on time (Nowak, 1970). However, the government's success in improving resource revenue from the tax is not only determined by the awareness and tax compliance in implementing the fulfillment of the tax obligations, but also the ability of personnel in terms of training, research and monitoring through examination of the truth of the reports submitted by the taxpayer to the sense of justice in enforcement of tax law (Soup, 1970). Unlike other law enforcement, enforcement of the tax law does not begin from evil criminal acts and work based on the suspects, but starting from reading the tax reports and look for finding whether there are indications evasion or not. Tax audit rely only little information is centralized or in other words automatically checks Tax Return (Das-Gupta et al, 2004).

Implementation of the tax law enforcement is not only influenced by the ability of officials in fostering the taxpayer, but also influenced by organizational culture (Soekanto, 2005). Changing organizational culture conducted by the Directorate General of Taxes is thorough and comprehensive, covering changes in organization, technology, and the application of human resources management professionals to the staff of Tax Directorate as an increase in moral, ethics, and integrity by implementing employee code of conduct. Vision, mission and values developed in order to support the changes made.
Some research suggests that organizational culture has positive influence on work motivation (Tolkah Mansur, 2009). An organizational culture that is measured in the study using indicators involvement, consistency, adaptability, danmisi developed by Denison and Misra (1995). The results support the studies that have been conducted by Koesmono (2005), which also proves the existence of a positive and significant influence of organizational culture on employee motivation. An employee professional can not escape the fact that they are individuals who also have needs, desires, and expectations from work. The desire to meet this need that will affect the work motivation within each individual to do everything better than others in their efforts to achieve the goal. Motivation to work on employees can be influenced by several factors including organizational culture and job rotation. Masrukhin dan Waridin (2006) revealed that each organization has an organizational culture that serves to establish rules or guidelines in thinking and acting in achieving the set goals. This means that an organizational culture that is growing and is well maintained will be able to spur the organization towards better development. In addition, the main emphasis in the change and development of organizational culture is trying to change the values, attitudes and behavior of members of the organization as a whole.

From the above discussion, the question arises, whether the motivation of the work of the law enforcement in the implementation of the tax law enforcement can influence the increase in tax revenue. Based on this, the researchers are interested in conducting research on how big the influence of organizational culture on the implementation of the rule of law and its implication on raising tax revenue.

Literature Review 
As a guideline to determine the fulfillment of the principle of fairness in legislation the following four conditions must be met (Adam Smith, the Canons of Taxation, in Stiglitz, 2000):

1) Equality or similarity, means that the same state or persons residing in the same state should be taxed the same.

2) Certainty or the rule of law, tax law, both will always be able to provide legal certainty to taxpayers, when he had to pay, what rights and obligations, who is the subject and the object of the tax and how much tax.

3) Convenience of payment, meaning the tax should be levied at the right time, which is when the taxpayer has money or as close to the time of receipt of the second income is concerned.

4) Economics of collection, meaning in shaping tax legislation that recently the drafter should consider that the cost of collection should be relatively small compared with the tax money coming in.

Many tax laws that have been established but is not running properly, or in other words the rule of law can not run as expected. This happens because there are still some obstacles encountered in law enforcement efforts (Soerjono Soekanto, 2005). Next described factors that affect the enforcement of the Directorate General of Taxation is can be described as follows:

1) Factors device or its Legal Rules

Device or rules of law which are lacking and clearly can pose a lot of interpretation in the implementation of the Act in order to be effective, in accordance with its objectives, there are some principles that include:

a) Act is not retroactive, meaning that the law should only be applied to the events referred to in the legislation, as well as occurring after the law was declared.

b) The law made by the higher authorities, has a higher position anyway.

c) The law of a specific nature aside the laws of a general nature, if the same maker.

d) The law in force later, canceling the laws in force earlier.

e) The law is inviolable.

f) The law is a means of achieving spiritual and material welfare for people and personal.

2) Areas of Law Enforcement

Law enforcement that the tax authorities or more specifically, functional examiner. Every law enforcement in this case the examiner has a functional position and role. Position is a social position that may be high, medium or low. Within these positions contained within it rights and obligations. Rights and obligations of such a role or role. Therefore, a person who has a certain position, usually called the holder of the role (role occupant). A role, can be translated into the following elements:

a) The role of the ideal (ideal role)

b) The role that should be (expected role)

c) The role is considered by themselves (perceived role)

d) The role is actually done (actual role)

Ideal for the role and the role it is supposed to come from the other side, while the role of which is considered by themselves and the actual role do comes from the personal self. However, in this case only limited to the role that should be and the role that actually do. If in fact there is a gap between the role that should be the role is actually done, then there has been a gap role (role-distance).

Question of the role is important, because in the discussion of the law enforcement agencies will be many obstacles arise due to the gap role. The gap this role must involve the real behavior of the executive law enforcement.

3) Factors Facilities and Amenities

In the absence of specific facilities and amenities, it is impossible for law enforcement to take place smoothly. Is meant here is the entire facility or facilities to support law enforcement. If these things can not be met, it is impossible for law enforcement to reach its goal. Supporting facility among other law enforcement efforts such as data sources, data accuracy, data rate, and other amenities.

4) Factor of Culture
As a system, the law covers the structure, substance and culture. The structure includes a container or the shape of the system, such as the order of the formal legal institutions, the relationship between these institutions and so on. The substance with the content of legal norms as well as the formulation and events for enforcing the law enforcement and seeking justice. While cultures (systems) law basically covers the values underlying the applicable law, the values of which are abstract conceptions regarding is considered good and are considered bad.

5) Factors Society

Society is the environment in which they may apply or applied. Behavior within the community itself often a contributor ineffectiveness law enforcement efforts, for example, there are many bribe, manipulate behavior for reporting income and taxes payable, and the lack of community participation in controlling the negative behavior of the apparatus of the tax authorities and taxpayers.

In everyday people's lives can not be separated from the cultural ties that were created. Organizational culture needs to be improved by reducing the values that are less relevant to the development needs of the organization and employees must proceded by intense research activity and series to discover the cultural values that are outdated and seek to identify new values (Kurniawan, 2006).

According to Schein (2010: 18), organizational culture is defined as follows:

"The culture of a group can now be defined as a pattern of shared basic assumptions learned by a group as it solved its problems of external adaption and internal integration which has worked well enough to be considered valid and therefore to be taught to new members as the correct way to perceive, think, and feel in relation to those problems."

The culture of a group is defined as a pattern of assumptions learned by a group to solve the problem either external adaptation and internal integration undertaken to consider and then teach it to members of the organization as a form of acceptance, thoughts, and feelings are true.

According Colquitt (2011: 528), organizational culture is defined as follows:

"Oganizational culture as the shared social knowledge within an organization regarding the rules, norms and values that shape the attitudes and behaviors of its employees. Culture is social knowledge among members of the organization. Employees learn about most important aspects of culture through other employees." Organizational culture is a part of social knowledge in the organization with regard to rules, norms and values that shape the attitudes and behaviors of employees. Culture is a social knowledge among members of the organization adalam. Members of the organization must learn the important aspects of culture.

According to Robbins and Judge (2007: 256), organizational culture are:

"A system of shared meaning held by members that distinguishes the organization with other organizations."

Meanwhile, according to Armstrong (2005: 384), organizational culture is a pattern of values, norms, beliefs, attitudes, and assumptions that are not articulated, but the shape and define the way people behave and solve a problem. Where the value of which is believed to lead to things and be critical of how people and how organizations. While norms are unwritten rules of behavior.

It can be concluded that the definition of organizational culture in this study is the value system of the organization held by members of the organization, which then affects the way to work and behave of the members of the organization.

Changes sustainable organizational culture can be created through changes in the organization, but the organizational culture as the existing software in the organization can only be changed through organizational climate (sitty Yuwalliatin, 2006). Robbins (2006) and Hofstede and Bornd (1984) states that organizational culture is measured using several factors, namely professionalism, distance from management, open attitude clerks, order clerks and employee integration. 
Organizational culture positive influence on work motivation (Tolkah Mansur, 2009). An organizational culture that is measured in the study using indicators involvement, consistency, adaptability, and mission developed by Denison and Misra (1995) The results support the studies that have been conducted by Koesmono (2005), which also proves the existence of a positive and significant influence of organizational culture on employee motivation.

In accordance with the laws of behavior that the behavior was directed at a goal (Kast \& Rozenzweig 1979), then in terms of organizational life, work behavior is usually directed to produce work performance (Gibson et al, 1996). Therefore, a positive work behavior, which is characterized by high employee motivation will be shown with more good results of the employee, both in terms of quantity and quality (Siagian 1995).

Deepening the tax compliance can be done with the approach of multiple perspectives, which can be seen as a problem of public finances, enforcement of tax designing organizational, labor supply, or ethics, or a combination of all of these problems (Andreoni et. Al., 1998). Tax enforcement means the enforcement in the field of taxation. Questions about the deterrent effect associated with a penalty and the possibility of undetected centered on two literature that tax compliance and enforcement.

Tauchen et.al. (1989) states that the tax audit has direct and indirect influence on tax revenue. The direct effect arises from the penalty and of Tax Return had been examined, while the indirect effect arising from the special effects and general effects (specific deterrence and general deterrence). The special effects in question is the taxpayer who has checked into a more compliant, and the general effect is that if these checks increase taxpayer compliance for others who have not been examined.

Niu (2009) in her study mentions that after the tax audit, the taxpayer then report higher sales growth than before the tax assessment in the amount of 17.49 percent. Then in 2010 Niu back doing research result is that the taxpayer who has examined its tax return to report sales growth of 2.63 per cent higher than the taxpayer who had not previously examined. It also affirms Alm et.al. (1992) in his research that tax revenues will increase as a result of the tax audit and penalty levels are high.

Fatt (2002) states that the tax audit is separate from the tax investigation. Tax inspectors never reported benefits arising from the examination (Dubin, 1990). Another benefit of this examination means that the increase in tax collection from the taxpayer were not checked or examined, arising from an increase in the possibility of inspection.

Brondolo (2009) states that the tax revenues will increase temporarily as a result of the collection of tax on tax arrears of a small part the individual taxpayer and the taxpayer Badan.Selanjutnya, Waluyo $(2008,238)$ stated that the increase in the number of tax arrears from time to time show the number Very large. Increasing the amount of tax arrears can not yet be offset by redemption activity, but by doing so in general tax revenue increases in taxation, the tax arrears it is intended to be implemented tax collection action that has force of law.

Based on the above, the researchers hypothesized that "organizational culture affect the implementation of the rule of law as well as the implications for the increase in tax revenue".

\section{Methodology}

This study aims to determine how much influence of organizational culture on the implementation of the rule of law and its implication on raising tax revenue. This research is useful for the development of science and solve problems based on theories that have been there. Thus, in accordance with the purposes and objectives to be achieved, the research uses descriptive verification method.

Descriptive method is a method used to describe or analyze a result of the study but not used untk make broader conclusions (Sugiyono, 2009: 29). While M.Nazir stated that the descriptive method is a method in researching the status of human groups, an object, a condition, a system of thought, or a class of events in the present.

Verification method is a method of research that is based on the philosophy of positivism, is used to examine the population or a particular sample in order to test the hypothesis that has been set (Sugiyono, 2009: 13).

Data collection method used survey method, where data were collected from a sample that has been determined and captured using data collection tools in the form of a questionnaire.

Before being used for data collection in the field, the questionnaire needs to be tested for validity and reliability. For used 30 respondents drawn at random. Testing the validity of the analysis was done by using Product Moment Pearson correlation coefficients (Pearson Product-Moment Correlation coeficient) with the following formula:

$$
r_{y x}=\frac{n \sum X Y-\left(\sum X\right)\left(\sum Y\right)}{\sqrt{\left\{n \sum X^{2}-\left(\sum X\right)^{2}\right\}\left\{n \sum Y^{2}-\left(\sum Y\right)^{2}\right\}}}
$$

Information:

$\mathrm{X}$ : Score items used instruments

Y: Total Score instruments in these variables

$r_{x y}$ : Pearson correlation coefficient between item instrument used with the variable in question

$\mathrm{n}$ : Number of respondents

Hypothesis statistics:

$\mathrm{HO}$ : Item $\mathrm{i}^{\text {th }}$ the questioner is invalid

$\mathrm{H} 1$ : Item $\mathrm{i}^{\text {th }}$ the questioner valid

Testing criteria: reject H0 if the correlation coefficient $r>0.30$, meaning that all items that have a correlation $>0.30$ can be said to be valid. Item is a good item to have a correlation between 0.30 to 0.70 .

Reliability testing questionnaire used Cronbach's Alpha with the following formula:

$$
\alpha=\left(\frac{K}{K-1}\right)\left(\frac{s_{r}^{2}-\Sigma s_{i}^{2}}{s_{x}^{2}}\right)
$$

Which :

$\alpha=$ Cronbach alpha reliability coefficient

$\mathrm{S}^{2}=$ Variance overall score

$\mathrm{Si} 2=$ Variants of each item

$\mathrm{k}=$ number of the questions

After the value of reliability coefficient is obtained, it is necessary to set a coefficient of reliability smallest deemed reliable. In this case Sugiyono (2006) states that the reliability coefficient of between 0.60 to 0.80 is good enough for basic research purposes.

Population refers to a whole group of people, events or things of interest that want meticulous researcher (UmaSekaran, 2007; 121). Furthermore, according to Suharsimi Arikunto (2006: 107) to determine roughly how much members of the population will be taken, then when the subject is less than a hundred, better taken all that research is the study population (census). So based on the above statement, then the target population is a sample of this research is done by taking the entire Tax Office in West Java, West Java Regional Office I and II as many as 35 offices.

Data obtained from the research results then processed using data analysis techniques ie Partial Least Square (PLS). PLS according to Wold in Ghozali (2008) is a powerful analytical method therefore not based on many assumptions. This study uses PLS as data analysis techniques with Smart PLS software version 2.0.M3. PLS method has its own advantages include the data should not multivariate normal distribution (with a scale indicator categories, ordinal, interval until the ratio can be used on the same model) and 
the sample size should not be large. This is in accordance with the number of samples in this research is 31 respondents. Although the PLS is used to confirm the theory, but it can also be used to describe the presence or absence of a relationship between the latent variables.

Stages are used to analyze the data, namely:

1) Confirmatory Factor Analysis. Church and Burke in Widhiarso (2004) says that the technique Factor Analysis is a technique that is adequate in analyzing a simple model in the functioning of empirical constructs (factors) in a structural model. One of the advantages of Factor Analysis is a level of flexibility when applied to a hypothetical mode of the complex. The purpose of this analysis is to explain and illustrate by reducing the number of parameters (Widhiarso, 2004). Confirmatory Factor Analysis constructs used to see the validity of each of the indicators and to test the reliability of the constructs. Criterion validity of the indicators measured by convergent validity. Indicators be valid for convergent validity but the loading of 0.7 to study the early stages of the development of the loading of 0.5 to 0.6 is considered adequate, and may be indicated by the Average Variance Extracted (AVE) is above 0.50. Reliability constructs measured by Composite Reliability and Cronbach Alpha. Constructs said to be reliable if it has the Composite Reliability and Cronbach's alpha above 0.70 (Ghozali , 2008).

The study emphasizes the development model to be tested for compliance, including studies using structural equation modeling. Structural models were evaluated using Goodness of Fit model, which shows the difference between the values observed and the values predicted by the model. In the regression model, the Goodness of Fit (conformance testing) showed that the value of $\mathrm{R} 2$ above $80 \%$ is considered good (ILT, 2008).

2) multiple regression analysis, the purpose of the direct influence between the constructs based on hypotheses that have been expressed and structural equation model, the regression equation with the constants or unstadardized are as follows:

$Y=\beta_{0}+\beta_{1} X_{1}+\beta_{2} X_{2}+\beta_{3} X_{3}$

$\mathrm{Z}=\beta_{0}+\beta_{1} \mathrm{X}_{1}+\beta_{2} \mathrm{X}_{2}+\beta_{3} \mathrm{X}_{3}+\beta_{4} \mathrm{Y}_{1}+\mathrm{e}$

3) The path analysis (path analysis)

The next step to test the contribution of the path coefficients indicated in each diagram the path of a causal relationship between the constructs, used Path Analysis. Path Analysis will reveal the influence of direct and indirect effect between constructs, based on the standardized regression coefficients.

4) Hypothesis Testing and Interpretation

To test the hypothesis in this study conducted by Student's $t$ statistical test. These statistical tests of significance and its value can be done by using the Smart PLS. The criteria used is the hypothesis is accepted if the student's $t$ test statistic is greater than 1.96 and is rejected if less than or equal to 1.96 .

\section{Empirical result}

Organizational culture affect the implementation of law enforcement as well as the implications for the increase in tax revenue. The hypothesis testing is done through the $t$ test with the provisions reject Ho if t-statistic greater than 1.96 or should reject Ho if t-statistic is less than 1.96. The estimation results of the relationship between the constructs can be seen by the following table:
Tabel 1: Significance Tests Influence of Organizational Culture to the Implementation of Law Enforcement and the Implications on Increased Tax Revenue

\begin{tabular}{llllll}
\hline & $\begin{array}{l}\text { Original } \\
\text { Sample } \\
(\mathrm{O})\end{array}$ & $\begin{array}{l}\text { Sample } \\
\text { Mean } \\
(\mathrm{M})\end{array}$ & $\begin{array}{l}\text { Standard } \\
\text { Deviation } \\
(\text { STDEV })\end{array}$ & $\begin{array}{l}\text { Standard } \\
\text { Error } \\
(\text { STERR })\end{array}$ & $\begin{array}{l}\text { T Statistics } \\
(\mid \text { O/STERR })\end{array}$ \\
\hline $\begin{array}{l}\text { BO } \\
(\mathrm{X})-\end{array}$ & & & & & \\
$>$ PH & $-0,038$ & $-0,022$ & 0,228 & 0,228 & 0,165 \\
$(\mathrm{Y})$ & & & & & \\
$\mathrm{PH}$ & & & & & \\
$(\mathrm{Y})-$ & & & & & \\
$>$ & 0,563 & 0,495 & 0,259 & 0,259 & 2,178 \\
$\begin{array}{l}\text { PPP } \\
(\mathrm{Z})\end{array}$ & & & & & \\
\hline
\end{tabular}

\section{Source: Data processed}

Based on the above table it can be seen that the influence of organizational culture on law enforcement were not significant $(t$ $=0.165$ ) with a path coefficient of -0.038 , and the influence of law enforcement to increase tax revenues, significant $(t=2.178)$ with a path coefficient of 0.563 . These results indicate that the influence of organizational culture on an increase in tax revenue is very small, it is thought to occur because of bureaucratic reforms undertaken DGT in an effort to improve organizational culture are either not supported by the reform of the organizational culture of other agencies so that it becomes difficult to be accepted by other stakeholders because it is considered the organizational culture in the DGT is not "friendly". For example, all of the services provided to taxpayers free of charge. And then, if one day there is a person who levies the tax authorities, the taxpayer can easily make a complaint then be taken in a transparent manner. While that is happening in other agencies, for example in terms of making identity cards, frequent extortion, where citizens who want to make ID cards held a number of fees beyond the actual administrative costs. It occurs mainly in people who have recently moved and did not have sufficient documentation is needed in the management of the filing of ID cards (such as moving letter, the old ID card, etc.), so that not a few people who have more than one identity card. It is difficult for the DGT when extending the program taxpayer, ie increasing the number of taxpayers TIN spreading in office to citizens over the age of 17 years. As happened in 2007, in which not a few of the citizens who receive more than one of the TIN.

Table 2: Coefficients Path Value And The Value Of R-Square

\begin{tabular}{lllll}
\hline Variabel & Variabel & Koefisien & t- & \multirow{2}{*}{ R Square } \\
Endogen & Eksogen & Jalur & statistic & \\
\hline $\mathrm{Z}$ & $\mathrm{X}$ & 0,425 & 1,620 & \multirow{2}{*}{0,3566} \\
\hline
\end{tabular}

Source: Data processed

Through the above table it can be seen that the organizational culture variable (X) and law enforcement (Y) effect on the variable of increased taxes revenue $(\mathrm{Z})$ of 0.3566 , or $35.66 \%$, while the remaining $64.34 \%$ influenced by other variables not observed in this study.

Decomposition model is a model that emphasizes the influence of the nature of causality between variables, both the effect of directly or indirectly within the framework of path analysis, in this case the variables influence organizational culture $(\mathrm{X})$ to increased taxes revenue $(\mathrm{Z})$ through law enforcement $(\mathrm{Y})$,

Table 3: Correlation Coefficient Matrix

\begin{tabular}{llll}
\multicolumn{4}{c}{ Table 3: Correlation Coefficient Matrix } \\
\hline & $\mathrm{X}$ & $\mathrm{Y}$ & $\mathrm{Z}$ \\
\hline $\mathrm{X}$ & 1,000 & & \\
$\mathrm{Y}$ & 0,271 & 1,000 & \\
$\mathrm{Z}$ & 0,414 & 0,336 & 1,000 \\
\hline \multicolumn{4}{l}{ Source: Data processed }
\end{tabular}

Using the information the correlation coefficient between the latent variables above, and then to determine the magnitude of direct and indirect influence as follows: 
Table 4: Large Influence of Organizational Culture on Law Enforcement and Increased Tax Revenue Implications

\begin{tabular}{|c|c|c|c|c|c|c|}
\hline \multirow[t]{2}{*}{$\begin{array}{l}\text { Exoge- } \\
\text { nous } \\
\text { variables }\end{array}$} & \multirow[t]{2}{*}{$\begin{array}{l}\text { Path } \\
\text { Coeffi- } \\
\text { cient }\end{array}$} & \multirow[t]{2}{*}{$\begin{array}{l}\text { Direct } \\
\text { Influ- } \\
\text { ence } \\
(\%)\end{array}$} & \multicolumn{2}{|c|}{$\begin{array}{l}\text { Effect of } \\
\text { Variable } \\
\text { Endoge- } \\
\text { nous } \\
\text { Against (Z) } \\
\text { through } \\
(\%):\end{array}$} & \multirow[t]{2}{*}{$\begin{array}{l}\text { Indirect } \\
\text { Influ- } \\
\text { ence } \\
(\%)\end{array}$} & \multirow[t]{2}{*}{$\begin{array}{l}\text { Total } \\
\text { Influ- } \\
\text { ence } \\
(\%)\end{array}$} \\
\hline & & & $X$ & $\mathrm{Y}$ & & \\
\hline BO (X2) & 0,425 & 18,09 & - & $\begin{array}{l}6,5 \\
0\end{array}$ & $-0,49$ & 17,60 \\
\hline PH (Y) & 0,563 & 31,72 & $\begin{array}{l}6,5 \\
0\end{array}$ & - & $-12,82$ & 18,90 \\
\hline Total & & & & & & 35,66 \\
\hline
\end{tabular}

Source: Data processed

Based on the analysis of direct and indirect effects of the above, it can be seen that the influence of organizational culture (X) to law enforcement $(\mathrm{Y})$ and its implications for the increase in tax revenue $(\mathrm{Z})$ is at $6.50 \%$. These results suggest that organizational culture both within law enforcement implications to increase tax revenue by $6.50 \%$, in line with the results of research conducted by Tolkah Mansur (2009), Zulian Yamith (2005), and Masrukhin \& Wahidin (2006). Nevertheless, the results of this study indicate that the effect is very low, where the effect is very small as far below $80 \%$. This is thought to occur because there are other variables that much greater influence on the increase in tax revenue.

\section{Conclusion}

Based on the formulated problem, research objectives set and the formulation of hypotheses, and after discussion, supported by relevant data and theory, researchers can draw the conclusion that there is an influence of the culture of the organization is to increase tax revenues through law enforcement.

Small effect demonstrated in this study because of several things, including bureaucratic reforms that affect the organizational culture of taxation is not supported by the reform of organizational culture in other agencies, the demotivation law enforcement, and at the same time the issuance of the tax holiday policy for industry-specific industries so that in the short term this policy actually leads to a decrease in tax revenue.

To improve the effectiveness of law enforcement in the field of taxation, DGT is very necessary to inculcate values that can spur employees to be more innovative in their work and bold in taking the decision is not contrary to the provisions in force. DJP need to inculcate accuracy in this case the attention to detail to employees, this attitude is important to cultivate prudence so as to foster public confidence.

In addition, it is equally important that in preparing the tax revenue target should be based on revenue potential, not only based on the realization of revenue from the previous year. The problem is, if the target is already reflecting the potential tax revenue that is exactly what is not. This is because the government's ability to collect taxes showed leaks, as happens in cases of tax evasion lately.

\section{References}

[1] Alm, James, Jackson, Betty, McKee, Michael. 1992. Institutional Uncertainty and Taxpayer Compliance, The American Economic Review, Vol. 82, Issue 4, 1018-1026

[2] Armstrong, Michael. 2005. A Handbook of Human Resource Management Practise : Fully update to reflect current thinking, practice and research, 9th edition, Kogan page Limited : London

[3] Andreoni, Erard and Feinstein. 2006. Audit Certainty, Audit Productivity, and Taxpayer Compliance, National Tax Journal, Des 2006

[4] Brondolo, John. 2009. Collecting Taxes During an Economic Crisis :Chalanges and Policy Options, IMF Staff Position Note, SPN/09/17, July 14, 2009
[5] Das-Gupta.Arindam, Ghosh. Shanto, Mookherjee. Dilip,. 2004. Tax Administration Reform and Taxpayer Compliance in India, International Tax \& Public Finance, 11, 575-600, Kliwer Academic Publishers http://dx.doi.org/10.1023/B:ITAX.0000036692.95048.00

[6] Dubin, Jeffrey A., Wilde, Louis L., 1988, An Empirical Analysis of Federal Income Tax Auditing and Compliance, National Taxation Journal, vol. 41(I), pp.61-74.

[7] Fatt, Choong, Kwai. 2002. Tax Audit and Tax Investigations, 11 Sep 2002.

[8] Koesmono H, Teman. 2005. Pengaruh Budaya Organisasi Terhadap Motivasi dan Kepuasan Kerja serta kinerja Karyawan Pada Sub Sektor Industri Pengolahan Kayu Ekspor di Jawa timur.Disertasi. Universitas Airlangga, Surabaya.

[9] Kurniawan, Richard. 2004. SadarPajak, Kunci Pembangunan", Juara II pada Lomba Karya Tulis Perpajakan Nasional, DirjenPajak-Fisip UI.

[10] Niu Yongzhi. 2009. Taxpayers' Response to Warnings of a Possible Tax Audit: Do They Change Their Compliance Behavior?, New York State Department of Taxation and Finance.

[11] Niu, Yongzhi. 2010. Tax audit impact on voluntary compliance, MPRA Paper No. 22651, posted 11. May 2010.

[12] Nowak Norman D. 1970. Tax Administration in Theory and Practice: With Special Reference to Chile, New York: Praeger Publishers.

[13] Panca Kurniawan dan Bagus Pamungkas. 2006. Penagihan Pajak di Indonesia, Malang: Bayu Media.

[14] Robbins, Stephen. P and Judge,Timothy A. 2007.Organizational Behavior. Twelfth Edition. Pearson Education Inc.

[15] Shoup S. Carl. 1970. Public Finance, second printing, Aldine Publishing Company, Chicago.

[16] Sitty Yuwalliatin, 2006, "Pengaruh Budaya Organisasi, Motivasi dan Komitmen Terhadap Kinerja Serta Pengaruhnya Terhadap Keunggulan Kompetitif Dosen Unissula Semarang”, Jurnal Ekonomi dan Bisnis,Vol. 7 No. 2, Juli, p. 241-256.

[17] Sugiyono. 2009. Metode Penelitian Kuantitatif, Kualitatif dan R\&D, Bandung: Alfabeta.

[18] Suharsimi Arikunto. 2006. Prosedur Penelitian Suatu Pendekatan Praktik, Jakarta: RinekaCipta.

[19] Soerjono Soekanto. 2005. Faktor-Faktor Yang Mempengaruhi Penegakan Hukum, PT Raja GrafindoPersada, Jakarta.

[20] Uma Sekaran. 2009. Research methods for business, edisike 4, SalembaEmpat.

[21] Waluyo. 2008. Perpajakan Indonesia, buku 1 edisi 8, Salemba Empat. 